\section{Heroinavhengighet og behandling}

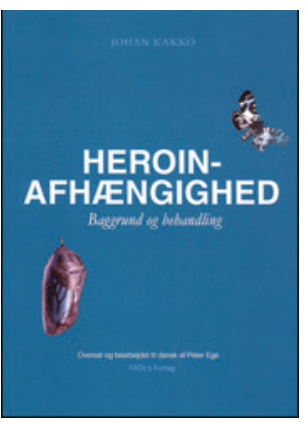

\section{Johan Kakko Heroinafhængighed}

Baggrund og behandling. $142 \mathrm{~s}$, ill. København: FADL's Forlag, 2012. Pris DKK 300 ISBN 978-87-7749-677-6

Målgruppen er helsepersonell og andre med interesse for heroinavhengighet. Dette er en populærvitenskapelig fremstilling av heroinbruk, og forfatteren beskriver pedagogisk og enkelt grunnlaget for medikamentell vedlikeholdsbehandling, som i Norge kalles legemiddelassistert rehabilitering. Denne behandlingen har i mange land, kanskje særlig i Sverige, stått i sentrum for en krass ideologisk preget diskusjon - for ikke å si krangel.

Fremstillingen bygger på et evidensbasert kunnskapsgrunnlag med utgangspunkt i forfatterens doktorgrad - utvidet med en drøfting av ulike behandlingsmodeller. Ulike dilemmaer i behandlingen beskrives og drøftes. Et eget kapittel omtaler behandlingen av gravide heroinbrukere.

Det er mye godt å si om denne boken, som i tillegg til å være en balansert fremstilling av synspunkter og forskning, også bæres oppe av et sterkt engasjement for pasientene - medmennesker med dyptsittende nevrobiologiske forstyrrelser i hjernen, slik forfatteren beskriver dem. I den siste delen gir han ordet til pasienter og pårørende. Dette gjelder pårørende til en pasient som døde etter behandling, en pasient som fortsetter å bruke rusmidler til tross for behandling, og en vellykket pasient som har funnet frem til en stabil tilværelse uten heroin. Disse stemmene får ordet på en levende måte og formidler sine budskap slik at det er tydelig at de har hatt innflytelse på forfatteren - slik de også får på oss.

I et forord skriver den kjente svenske rusforskeren Mats Fridell at denne boken er en nødvendig «manual» for behandlere. På tross av mange gode sider ved boken har jeg noen innvendinger. Mye av det Kakko kritiserer i Sverige, er avklart i Norge for flere år tilbake, slik det fremgår av retningslinjene for legemiddelassistert rehabilitering $\mathrm{i}$ vårt land. Boken er derfor ikke helt tilpasset norsk behandlingsverden. Når det gjelder fremstillingen av nevrobiologien, tar jeg også forbehold. Det er naturlig å forstå mange av abstinensreaksjonene etter opioidbruk som en tilbakeslående effekt i stressreguleringen, men det er ikke så naturlig å fremstille hypothalamushypofyse-binyre-aksen som et «antibelønningssystem». Det er riktig at heroin bare kan spores i noen få minutter, men virkningen er knyttet til metabolittene, og problemene skyldes ikke en av-ogpå-effekt av heroin. Det er videre neppe riktig at medikamentell vedlikeholdsbehandling «helbreder» hjernerelaterte, medisinske forstyrrelser.

Jeg har derfor en del motforestillinger og vil neppe, som Fridell, anbefale denne boken som en manual, og heller ikke som en grunnbok. Den gir imidlertid en god innføring i nevrobiologisk forståelse mer generelt og er også et levende innspill i den svenske debatten. Den er derfor egnet for de som er interessert i dette.

\section{Helge Waal}

Senter for rus- og avhengighetsbehandling

Oslo universitetssykehus, Ullevål

\section{Ja takk, begge deler!}

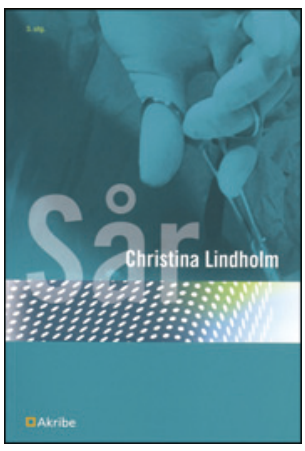

\author{
Christina Lindholm \\ Sår \\ 3. utg. 440 s, tab, ill. Oslo: Akribe, 2012 \\ Pris NOK 628 \\ ISBN 978-82-7950-122-0
}

Velkommen til tredje del i føljetongen av anmeldelser Bøker som heter $S A R$ !

Den trofaste og observante leser vil kanskje stusse over at denne anmeldelsen kommer litt i tidligste laget. Første anmeldelse ble nemlig publisert i tidsskriftet 7 . april 2005, og den andre kom på trykk 30. april 2009. Skulle vi dermed, i olympisk ånd, ha fortsatt med anmeldelser hvert fjerde år, burde denne tredje anmeldelsen først kommet på trykk i april 2013.

Men den norske oversettelsen av svenske Christina Lindholms tredje utgave, med det originale navnet Sår, er allerede ute for salg, og nok en anmeldelse er dermed på sin plass.

La oss ta opp tråden fra 2009. Da var det andre utgave av den danske boken Sår som ble anmeldt (1), og det ble poengtert at man ikke kunne unngå at den svenske og danske utgaven ble sammenliknet. Det gjelder også nå. Christina Lindholms tredje utgave frister med mange oppdaterte artikkelreferanser og flotte illustrasjoner. Hun har fått med seg mye av det som manglet i tidligere utgaver, i tillegg til flere elementer som undertegnede savnet i den danske utgaven fra 2009. Dette gjelder både omtale av biofilm og en grundig gjennomgang av «nye» behandlingsmuligheter som fluelarver (biokirurgi), honningprodukter og «polyhexamethylene biguanide» (PHMB). Christina Lindholm har utvidet det spennende historiske introduksjonskapitlet med en innføring av planter som tidligere er blitt brukt i behandling av sår. Dette siste er et stort pluss i margen når anmelderen er medlem av Norsk Botanisk Forening!

Den nye svenske utgaven stikker denne gangen av med pris for beste oppbygging og innholdsfortegnelse. Det er lett å finne frem til de store gruppene med sår (leggsår med sirkulasjonsforstyrrelser, trykksår, diabetessår, de vanskelige kreftsårene, ulike typer akutte sår og så videre), men undertegnede måtte bak i stikkordregisteret for å finne vaskulittsårene. Disse hadde på mystisk vis havnet i kapitlet om leggsår. For å gjøre det mer oversiktlig kunne vaskulittsårene vært i et eget kapittel om inflammatoriske sår, for eksempel sammen med pyoderma gangrenosum og sår hos pasienter med bindevevssykdom. Dette håndteres bedre i den danske boken. Danskene har i det hele tatt et bedre grep om dermatologiske og inflammatoriske tilstander hvor sårdannelse kan være et problem. Den danske versjonen er videre unik ved å ha et eget kapittel om sår i munnhulen, noe som mangler i den svenske. Lindholm er derimot best i sine ulike beskrivelser av kompresjonsbehandling, og hun har et utrolig godt kapittel om lokal sårbehandling. I det hele tatt utfyller disse to bøkene hverandre på flere områder. Noe liker jeg best $\mathrm{i}$ den danske versjonen, mens andre felt håndteres best av «söta bror».

Om jeg skulle få spørsmål om å velge enten den danske eller den svenske versjonen, kan jeg ikke annet enn svare: Ja takk, begge deler!

\author{
Brita Pukstad \\ Hudavdelingen \\ St. Olavs hospital \\ Litteratur \\ 1. Gottrup F, Karlsmark T, red. SÅR - baggrund, diagnose og behandling, 2.utg. \\ København: Munksgaard Danmark, 2008.
}

